\title{
TUDELA Y LUCENA
}

\author{
JOSÉ L. LACAVE
}

CSIC. Madrid

En varios escritos he sostenido la teoría de la pervivencia entre los judíos principales de Tudela hasta el siglo XV de unos hábitos aristocráticos, arabizados, que tenían su origen en Lucena, lo mismo que bastantes de las más distinguidas familias de aquella Comunidad judía '. El dato más firme en que me basaba para ello se encuentra en la kẹtubbâ del matrimonio Šelomoh ben Abasi-Fatbuena, hija de Yehudah ben Daud, fechada en 1441, en la que se afirma que fue כפי המנהג והתנאי שנוהגים ושהתנו ביניהם קהל קדוש אליסינה יצו' redactada 'según la costumbre y las capitulaciones que acostumbran y estipularon entre ellos [los miembros] de la Santa Comunidad de Lucena, Dios la guarde' ${ }^{2}$, mientras lo normal y corriente en las kẹtubbôt

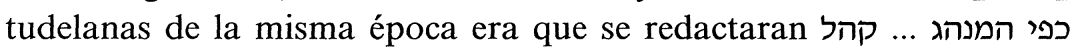
'según la costumbre ... de la Santa Comunidad de Tudela, Dios la guarde' 3 .

Sin desmentir la mencionada pervivencia de tales hábitos, corroborada, por otra parte, en la misma kẹtubbâ por el gusto en el uso de nombres y títulos árabes como signo de distinción, una nueva reflexión sobre esa cita de Lucena, así como sobre alguna otra mención de la prestigiosa judería de Al-Andalus en documentos

\footnotetext{
${ }^{1}$ Véase, por ejemplo, J. L. LACAVE, «La Comunidad donde nació Abraham ibn Ezrá», en F. Díaz Esteban (ed.), Abraham ibn Ezra y su tiempo. Actas del Simposio Internacional, Madrid 1990, 169-174 y J. L. LACAVE, «Un interesante documento hebreo de Tudela", en A. Mirsky - A. Grossman - Y. Kaplan (eds.), Exile and Diaspora. Studies in the History of the Jewish People Presented to Professor Haim Beinart, vol. II, Jerusalem 1991, 131-145.

${ }^{2}$ Publiqué esta kẹtubbâ en el segundo trabajo de los citados en la nota anterior; en la pág. 136 puede leerse el texto citado.

${ }^{3}$ Esas kẹtubbôt se pueden ver en mi edición de todas las kẹtubbôt españolas que se incluye en mi libro The Spanish Ketuba, que he entregado ya para que se publique en la serie Hispania Judaica de la Universidad Hebrea de Jerusalén y que muy pronto verá la luz.
} 
hebreos de Navarra de los siglos XIV y XV, me lleva ahora a pensar que entre aquellos judíos principales de Tudela, no sólo se produjo una cierta identificación entre esta población navarra y la famosa ciudad andaluza, sino que lisa y llanamente a Tudela le llamaron Lucena y así le siguieron llamando, compartiendo el nombre con el suyo propio de Tudela, hasta la expulsión.

Es un hecho conocido que a fines del siglo XI y sobre todo a lo largo del XII muchos judíos que huían de Al-Andalus, primero a causa de la invasión almorávide y luego por el fanatismo religioso almohade, se establecieron en diversas ciudades del entonces naciente reino de Navarra. Recuérdese el ejemplo siempre mencionado del insigne poeta granadino Mosé ibn Ezrá y su establecimiento en Estella. En concreto, en ese tiempo llegaron a Tudela, y allí se afincaron, unas cuantas familias distinguidas de Lucena que con el correr del tiempo serían las familias dirigentes de esa comunidad judía durante tres siglos ${ }^{4}$. Pues bien, creo ahora firmemente que aquellos judíos aristocráticos originarios de la ilustre judería andaluza le dieron a la población que les acogía el nombre de aquella ciudad de la que procedían.

A esta conclusión he llegado al tropezarme de nuevo con un documento ya publicado hace casi setenta años. En la actualidad preparo una nueva edición de los documentos hebreos que se guardan en el Archivo General de Navarra (Pamplona) y en el Archivo Municipal de Tudela ${ }^{5}$. Y uno de mis primeros pasos ha sido, lógicamente, repasar aquéllos de esos documentos que publicó $\mathrm{F}$. Baer en su magna colección documental ${ }^{6}$. Pues bien, en dicha colección ${ }^{7}$ se recoge el cuaderno de registro de un judío anónimo fechado en 1323 que se guarda con el número 9 en la famosa Caja 192 (de documentos hebreos) del Archivo General de Navarra. Y en ese cuaderno, en sus líneas finales, se puede leer el siguiente texto:

\footnotetext{
${ }^{4} \mathrm{He}$ explicado esto más extensamente en J. L. LACAve, Juderías y sinagogas españolas, Madrid 1992, págs. 143-144.

${ }^{5}$ A ello me ha inducido amablemente el Prof. Juan Carrasco, catedrático de Historia de la Universidad Pública de Navarra, en Pamplona.

${ }^{6}$ F. BAER, Die Juden im christlichen Spanien. Urkunden und Regesten. I: Aragonien und Navarra, Berlín 1929.

${ }^{7}$ Bajo el núm. 588, 3 (págs. 960-962) del volumen de F. BAER citado en la nota anterior.
} 


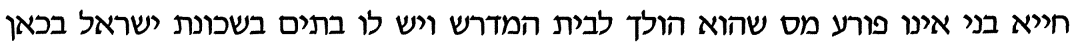

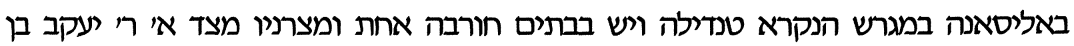
הרב ר' אברהם ן' אסקרה ומג' צדדים דרכי רשות במות הרבים.

\begin{abstract}
'Mi hijo Hiyyá no paga impuestos porque es un muchacho que aún acude a la madriza (escuela talmúdica). Él tiene unas casas en el barrio judío, aquí, en Lucena (Alisana), en el barrio periférico llamado Tendilla; esas casas están en ruina y sus vecinos son: por un lado, R. Yacaqob ben R. Abraham ibn Ezquerra, y por los otros tres lados, caminos públicos'.
\end{abstract}

El Prof. Baer, al encontrarse con esta mención de Alisana, es decir Lucena, sabiendo que no podía referirse a la ciudad andaluza, por la fecha y porque el documento hace claramente referencia a un lugar en Navarra, trató de localizar un lugar llamado así, Alisana, en el reino navarro y, no hallándolo, se declaró incapaz de identificarlo ${ }^{8}$, pero no obstante lo puso en relación con una apelación que conocía ante el tribunal judío de Tudela.

Para mí, ahora, no cabe duda de que en ese cuaderno de un judío anónimo se está hablando de la ciudad navarra a la que, por las razones ya explicadas, los judíos residentes en ella, además de Tudela, le daban el nombre de Lucena (Alisana). Y que lo mismo pasa en la mencionada kẹtubbâ del matrimonio formado por Šelomoh ben Abasi, también llamado Šelomoh Malaj, y Fatbuena, hija de Yehudah ben Daud. Un documento corrobora al otro. Creo además que ese barrio periférico llamado Tendilla puede identificarse con el llamado en otra kétubbâ La Planilla (las palabras españolas vienen a significar lo mismo), barrio o lugar tudelano que todavía se llama así hoy día y que se encuentra en el actual Paseo del Castillo, en la parte de ese paseo opuesta al río Ebro (recuérdese que el barrio judío desde 1170 hasta la expulsión estuvo en el castillo).

Cuando este artículo estaba ya madurado, una conversación fortuita me ha proporcionado un nuevo dato que viene a corroborar mi teoría de que los judíos tudelanos, al menos los principales, de los siglos XII-XV llamaron Lucena a Tudela. Charlaba yo con D. José Vicente Niclós, doctorando en Filología Hebrea en la Universidad Central de Barcelona, sobre su tesis doctoral que versará sobre

${ }^{8}$ Véase F. BAER, Op. cit., pág. 962, nota 2. 
la obra 'Eben bohan del escritor navarro Šem Tob ibn Šaprut. Me comunicó entonces su perplejidad porque en los manuscritos de esa famosa obra había visto un colofón datado en Tarazona, pero otro colofón estaba fechado en parte en Alisana, en iyyar del año 5165 (marzo 1405). Esto le tenía confundido, pues entendía, con buen criterio, que no podía tratarse de la famosa ciudad andaluza. Para mí no cabe duda, ese Alisana no es otra ciudad que Tudela, tan próxima además a Tarazona, donde está fechado el otro colofón visto por el Sr. Niclós.

En resumen, considero que está bastante clara la identificación Tudela-Lucena para los judíos tudelanos de los siglos XII-XV.

\section{RESUMEN}

Unas reflexiones del autor sobre la aparición del nombre de Alisana (Lucena) en documentos hebreos de Navarra le llevan a la conclusión de que Tudela fue llamada Lucena por los judíos originarios de la ilustre judería andaluza que se establecieron en la ciudad navarra.

\section{SUMMARY}

Some reflections of the author about the presence of the name Alisana (Lucena) in some Hebrew documents found in Navarra draw him to the conclusion that Tudela was called Lucena by those Jews having their origins in the distinguished Andalusian Jewry, who were established in that city of Navarra. 